\title{
Coupled Magmatic and Eruption Dynamics of the Puipui and Nearby Submarine Eruptions (Tonga)
}

\author{
Ken H. Rubin ${ }^{1}$, David ClaGue ${ }^{2}$, PETER Michael ${ }^{3}$, \\ CHRIS RUSSO $^{4}$, FRAN JENNER ${ }^{5}$, JIM GILL ${ }^{6}$, ERIN TODD ${ }^{7}$, \\ VAL FINLAYSON $^{1}$, STÉPHANE ESCRIG $^{8}$, BOB EMBLEY ${ }^{9}$ \\ ${ }^{1}$ Univ. of Hawaii Manoa, Honolulu, HI; krubin@hawaii.edu \\ ${ }^{2}$ MBARI, Moss Landing, CA; clague@mbari.org \\ ${ }^{3}$ Univ. of Tulsa, Tulsa, OK; pjm@utulsa.edu \\ ${ }^{4}$ CEOAS, Oregon State University, Portland, OR \\ ${ }^{5}$ CEPSAR, Open University, Milton Keynes, UK \\ ${ }^{6}$ Earth and Planetary Sciences, UCSC; gillord@ucsc.edu \\ ${ }^{7}$ Alaska SC, USGS, Anchorage, AK etodd@usgs.gov \\ ${ }^{8}$ EPFL, Lausanne, Switzerland \\ ${ }^{9}$ CIMRS, Oregon State University, Newport, OR
}

Volcanic deposits of the 2008 Puipui eruption on the intermediate-spreading NE Lau Spreading center reveal a small, compositionally and morphologically heterogeneous eruption with strong interplays between magma generation, crustal magma storage conditions, and eruptive processes. Puipui was discovered in Nov. 2008 by water column signals during a regional survey [1]), and subject of an ensuing May 2009 ROV and AUV eruption response expedition [2]. Mapping, sampling, and compositional analysis of Puipui lavas and tephra, and other nearby eruption deposits (including Maka and 3 historical eruptions at Tafu), reveal widely varying basaltic compositions derived from multiple parent magmas of enriched mantle sources, with little if any influence of the nearby Tofua Arc. The Puipui eruption is volumetrically small compared to other known deep sea eruptions [3], with mostly high effusion rate lava morphologies and localized tephra deposition [4]. Lava spatial compositional variations (e.g., bimodal $\mathrm{MgO}$ ), a high resolution ${ }^{210} \mathrm{Po}^{210} \mathrm{~Pb}$ eruption chronology, U-Th-Ra disequilibrium and $\mathrm{Sr}-\mathrm{Nd}-\mathrm{Pb}$ isotopes indicate that Puipui was fed by at least two magma compositions that produced spatially and temporally distinct deposits with differing trace element and isotopic compositions. At Puipui and nearby, mantle lithological variations and tectonically-controlled magma accumulation, storage, and eruption conditions appear to favor rapid melting and frequent (sub-decadal) eruption of largely unhomogenized parent magmas in Earth's fastest opening back-arc, the NE Lau Basin.

[1] Baker, J.E. et al., (2011) G-cubed 12, Q0AF02; [2] Rubin, K.H. et al., (2009) Eos Trans. AGU, 90(52), V43I-05; [3] Rubin, K.H., et al., (2012) Oceanography, 25, 142-157;

[4] Clague, D.A. et al., (2010) AGU Fall Meeting, T11E-03. 